\title{
Crossing the Borders of Identity Politics
}

\section{Disgrace by J.M. Coetzee and Agaat by Marlene van Niekerk}

\author{
Rosemarie Buikema
}

\author{
UTRECHT UNIVERSITY
}

\begin{abstract}
This text seeks to rethink the relationship between literature and the gendered construction of national boundaries. It does so by proposing a reconsideration of the terms singularity, difference and literariness while analysing two talked-about and best-selling postcolonial novels, Disgrace (1999) by J.M. Coetzee and Agaat (2004) by Marlene van Niekerk.
\end{abstract}

KEY WORDS J.M. Coetzee $\bullet$ difference $\bullet$ feminist literary theory $\bullet$ singularity - truth and reconciliation $\bullet$ Marlene van Niekerk

Those works that continue to feed our thoughts, conversations and emotions belong to great art, as defined by Nobel Prize winner Toni Morrison (1992). As opposed to amusement, these works of art do not only reveal something about the time and place in which they are functioning, but their singularity also has the potential to appeal over and over again to successive generations.

I am not claiming too much when in the course of this article I argue that both Disgrace (1999) by J.M. Coetzee and Agaat (2004) by Marlene van Niekerk will turn out to aspire to such greatness. Both novels raise problems that foreground the limits of our judgement and imaginative powers. Both novels embody a search, not so much for the right answers as for a state of susceptibility to the right questions. That's why in my contribution to this special issue, 'Writing across Borders', these two best-selling and prize-winning South African novels will guide my course. The cultural field surrounding Disgrace and Agaat gives me all the more reason

(C) The Author(s), 2009. Reprints and permissions: http://www.sagepub.co.uk/journalsPermissions.nav European Journal of Women's Studies, 1350-5068; Vol. 16(4): 309-323; 342615; DOI: 10.1177/1350506809342615 http:/ / ejw.sagepub.com 
for a further reformulation of my ideas about how and why to cross the borders of genres, disciplines and national cultures. The work of both has become, both nationwide and across the world, the focus of fierce debate with respect to the exact relation between literature and nation building, or, more generally speaking, the relation between literature and the construction of identity. The nature of such discussions is exemplary for the practice of interpretation within feminist studies in the 21st century. These two novels then, and the debate they have engendered, will act as a touchstone for proposing new coalitions between the different forms of studying culture. Thus, I hope to clarify my views on literature, boundary crossing and nationhood.

The narrative events in Disgrace are centred on the white South African literary scholar David Lurie, who makes the mistake of starting an affair with a coloured female student. He is subsequently dismissed and when he seeks peace and quiet on the farm of his daughter Lucy, both of them fall victim to violence by blacks. The novel appeared in 1999, exactly a year after the publication of the massive five-volume Truth and Reconciliation Commission of South Africa Report. Nearly every critic noticed that the story of the downfall of Professor David Lurie in Disgrace could be read as a description of the upheaval of a country in transition. The representation of this upheaval drew considerable national and international attention and sparked a continuous debate about what readers felt was Coetzee's pitch-black vision of the near future of South Africa.

The fact that there were clear-cut differences between black, white and gender-specific interpretations of the novel was a striking feature of this heated debate. Black readers and critics characterized the trenchant images of black violence as unproductive and stereotypical, while white readers saw the way in which the white Lucy takes her historical colonial guilt upon her shoulders as far too fatalistic (Banville, 2000; Gorra, 1999). Feminist readings, moreover, criticized the affirmation of the connection between passivity and femininity (see also Krog, 2004). For instance, the literary scholar Elleke Boehmer, who grew up in South Africa, wondered whether reconciliation in the context of a violent history is possible if women, in this case the white Lucy or the wife of the black Petrus, are still expected to bear gender-specific inequality and suffer in silence (Boehmer, 2002).

The novel Agaat was published five years later, in 2004. Its author is that other giant of South African literature, Marlene van Niekerk. In Agaat the reader witnesses the complex interaction between the dying white farmer's wife, Milla, and her black carer, Agaat. Milla is paralysed and unable to talk. Throughout the novel she tries to communicate with Agaat by moving her eyes. The two women, who are condemned to each other as patient and carer in the narrative present, share a heartrending and 
complex past that is unravelled bit by bit when Agaat reads fragments of Milla's dairy to Milla on her deathbed.

This novel too fell prey to a debate about the kind of things van Niekerk tries to say about the future of South Africa. Van Niekerk is an Afrikaansspeaking author who also writes in that language, and the South African reception of her novel concentrates specifically on the position allocated to the endangered Afrikaner minority culture in her vision of postapartheid South Africa. There were serious allegations from the politically conservative wing in particular, who blamed van Niekerk for squandering Afrikaner heritage. The cultural philosopher Johann Rossouw accused van Niekerk of pleading for the selfopheffing (voluntary elimination) of Afrikaner culture in favour of an opportunistic association with a globalizing English-speaking South African cultural elite (Rossouw, 2005). This led to a response by Andries Visagie, lecturer in Afrikaans and Dutch, who challenged Rossouw in an essay titled 'Agaat as Cultural Archive for the Future' in the digital South African journal Litnet (Visagie, 2005). Visagie agrees with the view that Agaat is a comment on the position of Afrikaner culture, but he is somewhat more sensitive to the novel's complexity. He is at a loss to understand how Rossouw can argue that van Niekerk treats Afrikaner culture as a lost cause in Agaat. The novel informs the reader at length about the richness of Afrikaner folksongs, proverbs, children's rhymes, crafts, agricultural methods, sound farmer's lore and other traditions still available to the Afrikaans-speaking South African. This is no selfopheffing, but the acknowledgement of a subcultural canon. What Agaat does undermine, according to Visagie, is the selfevident legitimacy and status of this cultural heritage in Afrikaner ideology. This status needs to be reformulated and that is why the novel may function as an archive of the future.

In the Netherlands, the academic reception of this recently translated novel has not been documented yet, but the journalistic reception of Agaat explicitly states that the lengthy novel's true meaning is allegorical. In an admiring review in the Dutch newspaper de Volkskrant (12 May 2006), Fred de Vries writes for instance that 'the strong psychological plot makes Agaat suitable for readers who do not know that much about South Africa. But the story goes far beyond that level. Agaat is an allegory of Afrikaner history of the past fifty years.' He carefully connects the dates of the family story to historical facts. The birth of Agaat coincides with the institutionalization of apartheid in 1948, and the birth date of another central character recalls the Sharpeville protest instigated by schoolchildren in 1960. De Vries sees the subtle symbiotic power play between the white Milla and the black Agaat as metaphorical for racial and political relations in South Africa. Milla's progressive muscular disease is symbolical of the exhaustion of farmland and the decline of Afrikaner hegemony. And so on. 


\section{ART AND COMMUNITY BUILDING}

The cultural and literary critics mentioned earlier are aware of the fact that in these specific novels art, on the one hand, and political and historical reality, on the other, have entered into a cogent relationship. It is of course true that works of art that are rooted in a period of political transition have a self-evident urgency and significance that cannot easily be claimed by all art. But even though the theme of political transition plays a prominent part in my research, it is not my main concern in this article. In less pressing political circumstances too, cultural artefacts can present opportunities for identification and are in that sense community building, which involves excluding and including groups. In the past decades, the identity-constituting effects of art and its concomitant inclusionary and exclusionary mechanisms have featured in various disciplines within the humanities. More generally, art and culture are seen as important producers of cultural memory in any context (see, for example, Bal et al., 1999; Buikema, 2006). The underlying idea is that cultural artefacts come about in a forcefield of global and local developments and that, as a sign system and text, the work of art has an openness and mobility that Bakhtin and Kristeva have described with the term 'intertextuality' (Bakhtin, 1982; Kristeva, 1974). Their concept of intertextuality is not exclusively limited to literary examples. Every sign system absorbs other intended and unintended sign systems. Bakhtin's famous dictum that 'the word does not forget its own path' always illustrates this process best. That is to say that every text bears the echoes of other texts and is also in dialogue with other texts, which implies that the attribution of meaning is a project that is never fully realized. A reader then performs a text, rather like a musician who performs a score (see also van Heusden, 2001). The performance determines the attribution of meaning, distributes emphasis and reinforces some strands while ignoring others.

Thus, in order to do justice to the intertextual character of the artefact, texts can only be studied adequately, when they are the object of research, from an interdisciplinary perspective. Interdisciplinarity is in essence not a frivolous type of academic research, as critics of cultural studies have frequently claimed, but a necessity compelled by the research object itself if a cultural phenomenon is to be approached in all its complexity. This is not to imply that every humanities discipline has come under the influence of these developments within cultural studies, but it is certainly the case that the study of texts and images from an intertextual and interdisciplinary approach has become dominant within literary studies and film studies in particular. A work-immanent approach is losing ground in musicology and art history as well. That is an important shift in the humanities in general. Aesthetic experience is no longer exclusively related to work-immanent aspects, but linked to material, political and historical circumstances as well. 
The outcome of research carried out from this angle has yielded some very valuable results and changed many a classic literary work's meaning forever. After Toni Morrison's lectures in American literature at Harvard University (see Morrison's Playing in the Dark, 1992), who could fail to grasp that the construction of freedom and humanity in Mark Twain's great American novel Huckleberry Finn (and the many films of the book) is inextricably connected to the slavery of nigger Jim? Who is still willing to present Jane Eyre as an unproblematic feminist heroine since Gayatri Spivak showed us that Jane's striving for economic independence, so applauded by the second feminist wave, was enabled by the unrestrained imperialism and slavery of 19th-century Britain (Spivak, 1985)? In the past decades, the teaching and research in feminist cultural criticism has been solidly anchored in this tradition of critical interpretations of culture. The intertextual approach has proven to be just as fruitful to research of popular culture as to art research. However, a specific practice has crept into the enthusiasm of committed humanities scholars: the concept of intertextuality is mainly applied as a form of ideological criticism. Many a committed research project in the humanities is in danger of reducing popular culture and artistic expressions to a message about the construction of gender, ethnicity, nationality and/or sexuality, thereby paying too little attention to the specific nature of the medium and the effect of its form. The approach to the artistic domain with a clear-cut political agenda involves the risk of losing sight in advance of what constitutes the specificity of art and literature. A few years ago, Jonathan Culler, a worthy advocate of intertextual interpretations of art and culture, concluded that, as a literary scholar, he had been so busy conceptualizing gender, race, identity, and subjectivity that not a word is spent on literariness in his prominent introductions to literary theory (Culler, 2000; see also Butler et al., 2000; Spivak, 2003).

To a certain extent this practice mirrors the white, black and gendered readings of Coetzee quoted at the beginning of my story and the concern about the loss of Afrikaner cultural heritage in response to van Niekerk's latest novel. I mean to attempt to redress this imbalance in proposing a synthesis of the work-immanent approach, so deservedly criticized in the past, and the contextual approach to art and culture that was so rightly taken on board. In other words, I would like to reassess the fruitfulness of the workimmanent approach and the method of meticulous textual analysis involved in it in order to attune and enrich the intertextual approach and avoid the risks inherent to identity politics in the interpretation of art. Form is what defines a work of art; form constitutes its singularity par excellence, which is why it will always withdraw from being appropriated by sheer identity politics. I have no wish to deny that issues of identity politics can be understood through and illustrated by a work of art. However, the fictive and imaginary character of art does imply that the way in which it represents political and historical themes deserves explicit methodological attention. 


\section{LITERATURE AS THE PERFORMANCE OF DIFFERENCE}

Let us return to the two contentious South African novels. Apart from the vehement debate about how to be a white citizen in post-apartheid South Africa that was caused by these two books, the most conspicuous similarity in the reception of Disgrace and Agaat is that both invariably seize readers by the throat. None of the academic and journalistic commentaries that I have read or listened to remained indifferent to these novels. As such, this is of course a significant literary phenomenon; and this ought to be the primary focus of literary and cultural criticism. We are living in a multimedial world increasingly dominated by visual culture, digital or not. How is it possible, then, that in this kind of world a written text can seize you, perturb you, become part of your consciousness? Critics like Susan Sontag and Walter Benjamin would have said perhaps that this is possible because literature is a work of art. Every work of art has a unique aura that leads to concentration and contemplation (Benjamin, [1935] 1974; Sontag, 1964). Roland Barthes calls a similar effect in photography the punctum, whose immediacy stirs the art critic although it withdraws from connotative signification (Barthes, 1980). Asking this kind of questions changes the focus from meaning to the signifier, to the materiality of the work. In the case of literature, such materiality is the specific literariness of the work.

But what is literariness? It is a question frequently asked and variedly studied in literary studies, to no fully satisfactory effect. In an attempt to describe literariness here, I would say that literariness is generally manifested where an awareness or consciousness of 'the real' is engendered by language. This term, the real, originates from linguistics as inspired by French psychoanalysis. Like the concepts of aura and punctum, it refers to that which produces an effect, but which is not embedded in the symbolic system. In other words, in this context 'the real' refers both to the deficit of language and to the surplus, i.e. excess, of the medium. From this perspective, literariness is language that reflects on its own performance. I have to admit that this sounds rather vague at first, but in the past decades semioticians of culture have managed to find a connection between awareness of the real and the process of attributing of meaning (Culler, 1981, 1983). Awareness of the real develops through difference and divergence. People experience the real at the moment the world appears to them in unexpected ways. I argue that the literary or artistic moment is the imitation of that process. Hence, it is the mimesis of the unexpected instead of the imitation of a familiar reality that creates awareness. Paradoxically, then, diverging linguistic forms make us aware of our conventionally coded ways of dealing with the world.

The nature and effect of literature is different from other social and cultural practices because of this specific form of semiosis. Mimesis of the divergent also accounts for the fact that literature in particular, although 
this is true for art in general as well, can focus on absolutely everything. But whatever it deals with, its most important effect is always the production of awareness. Becoming aware of difference. Literature performs an awareness of alterity, of the other, of what is new and different. Thus, literariness comprehends the dimension of language that has the capacity to reveal the world. It has the potential to create new realities, not by giving us what we want, but by dissecting and deconstructing our expectations. Literature does not present us with solutions for questions concerned with identity politics or other matters, but foregrounds those questions as such by telling stories and by situating characters in diverse locations and times.

\section{DISGRACE}

How does this process take place in Disgrace and Agaat? Which questions do Coetzee and van Niekerk raise in depicting certain characters, locations and times? How does the analysis of culture that I am advocating raise these texts above reductive readings that are exclusively based on identity politics and/or on allegory? Let us start with Coetzee: in Disgrace, Coetzee seems especially to be asking questions about the specific characteristics of language. Which different kind of languages are available to us? What can and cannot be achieved by language with respect to the relation of the subject to itself and the regulation of human interaction?

The investigation into the possibilities and limitations of language motivates every plot development in David Lurie's story. The most prominent example of this is Lurie's somewhat unthinking seduction of a female student in his class. He is summoned before a committee of enquiry consisting of his closest colleagues. If he is willing to tell the committee in just a simple phrase that he sees the error of his ways, that he has transgressed academic conventions, the problem will blow over and order will be restored. You tell us your story and we will offer our forgiveness. That is the function of language as exchange, as tradeoff. Because of Lurie's awareness of the reductive effects of that communicative function of language, however, the self-evident nature of it in this specific context becomes unstuck.

An exchange or tradeoff presupposes an abstract equality. There is no room for difference in an exchange. Language as a means of communication and thus as exchange, Lurie seems to be saying, allows me to confess guilt and to accept the consequences of my deeds, but it does not serve to reveal my deepest motives in unequivocal terms or to express remorse. He thus accepts his dismissal.

It is of course tempting to read this reflection on the scope of language in relation to perpetrators and victims as a comment on the truth and 
reconciliation process that had come to an end just before the publication of Disgrace. There is in fact no reason for not reading it in this way. Reports on the truth and reconciliation process not only focused on the stories of the victims of the apartheid regime but also, and especially, on the stories of the perpetrators. Perpetrators could divulge their story to a committee specifically set up for this purpose and would duly receive amnesty (see, for example, Coetzee and Nutall, 1998). This aspect became a target of much criticism because of the relative ease with which the perpetrators could clear their conscience by simply telling a pretty story (James and van de Vijver, 2001; Mamdami, 2001; Minow, 1998). Lurie's refusal to confess in order to be pardoned can be read as a critique on that political-historical reality.

However, there is a good reason to go beyond this broad contextual reading and to regard Coetzee's novel in the context of his other works. A preoccupation with the performative aspect of language has been a recurrent theme in his novels and essays since his debut Dusklands in 1974, thus preceding the work of the Truth and Reconciliation Committee in South Africa by 20 years (see also Attridge, 2005). Coetzee's impressive essay 'Confession and Double Thoughts' (1985; in Coetzee, 1992) testifies to his interest in this theme. In attempting to formulate a critique on any effort to hound the truth by means of a written or spoken confession and/or self-examination, he concludes that every confession involves 'double thoughts,' ulterior motives. He argues that the confessional process can never imply an unequivocal pursuit of truth and self-awareness because every revelation of a hidden truth also simultaneously serves another aim. In other words, the confessional mode leads to a paradoxical situation: the truth is veiled rather than unveiled. Only when confession is not aimed at self-preservation or meant to command sympathy and acceptance on the part of the listener/reader, there is a possibility that truth be revealed - as a matter of grace.

In the context of the pursuit of truth and the truthfulness of expressed regret, the use of language as unequivocal exchange - you will tell your story and I will seal your fate - advances the question of how justice can be done, and what justice should look like. That question resurfaces even more compellingly in the second half of Coetzee's novel. Having left Cape Town, Lurie moves in with his daughter Lucy who, with the help of coloured employees, manages a farm in the Eastern Cape. The apotheosis of this second part is the violence inflicted on father and daughter by acquaintances of Lucy's black employee Petrus. Lurie wishes to solve the injustice against his daughter in the same way he solved his own faux pas; by taking recourse to the law. Not by enforcing remorse or understanding the reason why, but through the economy of the law. Whoever breaks the law will be punished. With dismissal, a fine or detention. Again, such an exchange of guilt and penance makes it impossible to 
acknowledge that the histories and motives of everyone concerned are fundamentally different and cannot be weighed equally. Petrus refuses to report his friends, because when it comes to settling bills a white person still owes a black person.

Lurie's daughter, Lucy, knows that this point of view is the reality she has to live with. She refuses to report the crime and even accepts the child born from the rape as a metaphor of her symbolic guilt to the country that her ancestors took from her rapists. She accepts Petrus's protection in exchange for a larger share of the farm. Despite her father's persistent urgings to report the crime and go to court, the white Lucy accepts what has been done to her just as the Truth and Reconciliation Committee asks of the black population to give and forgive. No equivalent exchange, no justice, but a gift. A gift implies a fundamental acknowledgement of difference, even irreconcilable difference.

It is precisely for this dramatic turn in the plot that Coetzee is severely criticized by white and feminist readers. However, an allegorical interpretation that takes as its only guide the mirror plot of Disgrace and is too eager to accept the referentiality of a post-apartheid South Africa screaming for a revelation of its future, ignores an important not to mention essential plot line. I am referring to the reversal that Lucy's rape generates in David Lurie's consciousness. This brings us to the merits of a workimmanent reading in the context of the intertextual attribution of meaning. In innumerable places following the dramatic events at Lucy's farm, the vocabulary of confession, guilt and awareness seeps into the text. Lurie realizes that he is able to embody the consciousness of the rapists, but not that of his daughter Lucy. He already knows that he is able to become a perpetrator, but he is unable to use his imagination to identify with the other sex. The irretrievable difference for Lurie is not black versus white but man versus woman. This puts the white, black and genderspecific criticism of Disgrace in a wholly different perspective.

The estrangement between Lurie and Lucy increases because of Lurie's fruitless attempts to understand his daughter and convince her that she should move to a safer place.

When Lucy informs her father that she entirely accepts the consequences of the situation and renounces any claim of retribution, Lurie concludes that she is acting like a dog. This is true, she agrees, like a dog. Being dog-like, however, does not imply passive resignation as the South African Elleke Boehmer fears, nor a programmatic solution to a problem, an end point, as some white critics inferred from the text. It is an opportunity to remain open to the experience of the present and continue to be oriented on the future. Lucy abandons her possessions and rights and prepares herself for a new beginning with unforeseen opportunities. In the end, her choice seems to emphasize that justice can only be expected from a symbolic system that refuses the economy of exchange and legal procedure. 
Such an interpretation becomes probable if we apply the work-immanent approach and are made sensitive to the way in which the vocabulary of confession and awareness does not concern the thematic of the novel alone, but affects the language of the novel as well. Once Lurie realizes that his emphasis on the logic of justice will only distance him further from his daughter and her employees, he is able, through his dedication to writtenoff dogs and in his thinking about music, to approach a level of humanity he was lacking before. In the novel's closing pages, Lurie mostly finds himself among the dogs in their shelter, while thinking about music:

He sighs. It would have been nice to be returned triumphant to society as the author of an eccentric little chamber opera. But that will not be. His hopes must be more temperate: that somewhere from amidst the welter of sound there will dart up, like a bird, a single authentic note of immortal longing. As for recognizing it, he will leave that to the scholars of the future, if there are still scholars by then. For he will not hear the note himself, when it comes, if it comes - he knows too much about art and the ways of art to expect that. (Coetzee, 1999: 214)

Using staccato sentences Lurie enters the twilight zone between language and non-language, between human and animal, black and white, man and woman. The awareness that one can only become human in being dedicated to the other, to music, to difference, is a political effect of Disgrace's literariness, of Coetzee's sparse language, of the room for thought the reader is offered. Read within the context of post-apartheid South Africa, this complex stance does not necessarily obstruct the path towards reconciliation; but it highlights the as yet unbridgeable gaps between different political-historical histories and opens an outlook on human interaction that is not facile but 'real'. That is what art can contribute to the debates on identity and citizenship. The divergent story creates an awareness of our conventionally coded ways of dealing with the world. It liberates the signifier from entrenched correlations of meaning, provides the work with wings and the attribution of meaning with new and potential coalition partners.

\section{AGAAT}

Current political debates on culture, identity and citizenship tend to turn to concepts like hybridity, nomadism, cosmopolitism, diversity and the like. In my use of the concept of difference I implicitly have argued for a very specific interpretation of those concepts which all try to describe the multilayeredness and situatedness of the subject. In thinking about literature and citizenship and/or literature and national cultures, hybridity, nomadism or diversity are not so much politically correct concepts that 
pay lip service to the experiences of women, migrants, blacks and other politically, socially and culturally marginalized people, as the consequence of the fundamental singularity of visual and discursive works of art (see also Attridge, 2004; Braidotti, 2006). This singularity does not reside in the inviolable meaning that is buried in the deep structure of the work, as a work-immanent approach would assume. Singularity resides in the complex of intertextual and contextual machinations. So in the case of the literary work, the singular effect comes about through the interplay of language, genre and literary tradition, as well as the cultural and geopolitical context in which the work functions. I began my story with a brief sketch of the cultural and geopolitical context in which both Disgrace and Agaat have become part of a comparable cultural political debate. I have shown that as a literary event there is more to Disgrace than mere participation in a political debate. In conclusion, I would like to sketch briefly how Agaat differs from Disgrace as a literary event. Apart from imagining a country in transition, Agaat also sheds a light on a wholly different world. Thematically just as grand and burdensome, and equally concerned with concepts of language, justice and the law, with the representation of the un-incorporable other and difference, the style and choice of words in Agaat is strikingly suggestive. While Coetzee is economic with language - his sentences are terse, jagged, disembodied, almost mathematical, leaving aside their sometimes lyrical textual effect - Marlene van Niekerk's novel Agaat is a sumptuous linguistic orgy, a blazing volcano of words, an excessive mix of styles and genres.

For that reason, a description of the plot of this novel is in no way representative of its potential impact as a literary event. I will try nevertheless. More than 40 years ago, the white Milla inherited the settlement Grootmoedersdrift. She has ambitious plans for the land and the premises and learns to master traditional agricultural methods. In order to endure her loveless and childless marriage to Jak, Milla takes in the coloured Agaat as a foster child. She treats the neglected child like she treats the South African land: with traditional methods. She sways between regarding the child as a small animal that can be transformed into a human being through discipline and punishment and seeing it as an enigma that needs to be deciphered or as a potential source of love, gratitude and admiration that needs to be cherished. When about 12 years have past Milla becomes pregnant, contrary to all expectations. Agaat is demoted from adopted daughter to servant. Agaat's revenge on Milla is ingenious and has very complex effects. She deploys the stereotypical conduct of the wet nurse and the black mama and uses her love to steal Milla's son. The child, Jakkie, develops a symbiotic relationship with this self-appointed mother and from their son's earliest youth his biological parents, Milla and Jak, are of no account.

In the tradition of South African literature, the setting and themes of Agaat appear to typify the novel as a so-called plaasroman. This is an essentially 
conservative nationalistic 19th- and 20th-century colonial genre. Its prominent themes are the connection to the land, the spacious countryside, the motif of the lost son, the relation to earlier generations and especially the distinction between a white 'us' and a black 'them' (Coetzee, 1988; Jansen, 2005; Postel, 2006). However, in van Niekerk's novel the settlement is far from idyllic. Grootmoedersdrift is a hotbed of unfulfilled desire, failed investments and projects going nowhere, cold-heartedness, violence, revenge and tyranny. In that sense, van Niekerk innovates the traditional genre from a post-apartheid position, comparable to the way in which in the 1980s Angela Carter advocated playing a postmodernist feminist and postcolonial game with conventional themes and genres: 'I am all for putting new wine in old bottles especially if the pressure of the new wine makes the old bottles explode' (Sage, 1994). This would imply that Rossouw has a point: van Niekerk undermines classical Afrikaner values and sentiments. But that is not the whole story. More than in any other plaasroman the tie with the land and the spaciousness of the countryside are apparent in Agaat both through its themes and composition as well as in the limitless exploration of the linguistic sign. Van Niekerk investigates the possibilities of language to an extreme extent and it is indeed true that here she challenges the boundaries of the traditional plaasroman and its patriarchal, nationalist values. Her method fits Hélène Cixous's use of the French verb voler in the familiar double meaning of the word (Cixous, 1975). Innovating literary tradition is like an act of voler, a process of theft and flight. In van Niekerk's novel, flight transforms the stolen form, the signifier, into an almost palpable object that allows for the celebration and reappropriation of the colours and fragrances of the African land. Thus, reading for example about Milla's struggle against agricultural monoculture is not so much a mental as an almost physical experience. In the novel's structure, Milla's dying body acts like a text, an interactive source carrying the burden of a past event; it has memory; it is coded and conditioned but not fixed in time. In the meantime, the reader is inevitably caught in the tangle of love and revenge, innocence and guilt, justice and injustice, power and impotence.

It is also this brazen imaginativeness and nearly palpable embodiment of frustrated and corrupted desire that has made van Niekerk the target of the type of criticism voiced by Rossouw, who argues that the minute description of Milla's dying body, doomed to silence and at the mercy of the black Agaat, means that van Niekerk is squandering South Africa's cultural heritage.

Certainly in the case of a work like Agaat, such criticism implies an almost hostile view on art, an anti-literary reading of literature and a disregard of the paradoxical dynamics of power relations between the characters. In order to give an example of one of the many deregulating literary registers deployed by van Niekerk in the midst of the vortex of disaster 
and violence, I quote a random passage in which Milla Redelinghuys is thinking of Agaat while on her deathbed. The passage is an example of the succession of subtly shaded and suggestively fragrant miniatures. As I said before, Milla is paralysed, she is unable to speak and she is at the mercy of Agaat:

'Oh, I wish I could speak! I would ask her whether she remembers. The butterflies that we retrieved from the small pool. After the excessive out of season showers following the first year after I had found her. Too heavy to fly, surprised by rain. We fished them from the mud and blew the sticky edges of their wings apart until we saw a spot to hold them by. Cautiously, cautiously we divided the wings, like wet tissue paper, so they would not cling to each other.' (van Niekerk, 2007: 540 [English edn])

While the vocabulary of subjection to the law and its violation and of confession, guilt and awareness carries the weight of Disgrace, the power of Agaat lies in the unprecedented abundance of poetic language, in linguistic associations and stylistic experiments, in the deployment of novel words, images and streams of consciousness. Every little miniature, like the one cited above, shows that this novel does not lend itself to a univocal identity-constituting appropriation. At the same time, the experimental style and the poetic language demonstrate that in a context of racial and patriarchal violence, literariness and politics do not constitute separate domains. Far from wishing to reduce Agaat to a programmatic cultural studies object, I would recommend this unique and exemplary novel as a guide in further exploring the interaction between content and form, literariness, difference and politics in the years to come.

\section{REFERENCES}

Attridge, Derek (2004) The Singularity of Literature. London and New York: Routledge.

Attridge, Derek (2005) J.M. Coetzee and the Ethics of Reading. Scottsville: University of Kwazulu Natal Press.

Bakhtin, Michael (1982) The Dialogic Imagination: Four Essays. Austin: University of Texas Press.

Bal, Mieke, Jonathan Crewe and Leo Spitzer, eds (1999) Acts of Memory: Cultural Recall in the Present. Lebanon, NH: University Press of New England.

Banville, John (2000) 'Review of J.M. Coetzee, Disgrace', The New York Review of Books 20 January: 23-5.

Barthes, Roland (1980) La Chambre claire. Paris: Gallimard.

Benjamin, Walter (1974) 'Das Kunstwerk im Zeitalter seiner technischen Reproduzierbarkeit', pp. 471-508 in Gesammelte Schriften. Unter mitwirkung von Theodor Adorno und Gershom Scholem, Vol. 1, Part 2. Frankfurt am Main: Suhrkamp Verlag. (Orig. pub. 1935.)

Boehmer, Elleke (2002) 'Not Saying Sorry, Not Speaking Pain: Gender Implications in Disgrace', Interventions 4: 342-51. 
Braidotti, Rosi (2006) Transpositions. Cambridge: Polity Press.

Buikema, Rosemarie (2006) 'Literature and the Production of Ambiguous Memory: Confession and Double Thoughts in J.M. Coetzee's Disgrace', European Journal of English Studies 10(2): 187-99.

Butler, Judith, John Guillory and Kendall Thomas, eds (2000) What's Left of Theory? New Work on the Politics of Literary Theory. New York and London: Routledge.

Cixous, Hélène (1975) 'Le Rire de la Meduse', L'Arc (Simone de Beauvoir) 61: 39-54.

Coetzee, Carli and Sarah Nuttall, eds (1998) Negotiating the Past: The Making of Memory in South Africa. Oxford: Oxford University Press.

Coetzee, J.M. (1988) White Writing: On the Culture of Letters in South Africa. New Haven, CT and London: Yale University Press.

Coetzee, J.M. (1992) Doubling the Point: Essays and Interviews. Cambridge, MA and London: Harvard University Press.

Coetzee, J.M. (1999) Disgrace. London: Secker and Warburg.

Culler, Jonathan (1981) The Pursuit of Signs. London: Routledge.

Culler, Jonathan (1983) On Deconstruction: Theory and Criticism after Structuralism. London: Routledge.

Culler, Jonathan (2000) 'The Literary in Theory', in Judith Butler et al. (eds) What's Left of Theory? New Work on the Politics of Literary Theory. New York and London: Routledge.

Gorra, Michael (1999) ' "After the Fall". Review of Disgrace, by J.M. Coetzee', The New York Times 28 November; at: www.nytimes.com/books/99/11/28/ reviews/991128.28gorrat.html

Jansen, Ena (2005) 'Ek het maar net saam met die meisies gebly. Die representasie van vrouebediendes in die Suid-Afrikaanse letterkunde', STILET March: 102-33.

James, Wilmot and Linda van de Vijver, eds (2001) After the TRC: Reflections on Truth and Reconciliation in South Africa. Claremont/Athens: David Philip/ Ohio University Press.

Kristeva, Julia (1974) La Revolution du language poetique. L'Avantgarde a la fin du 19e siecle. Paris: Editions du Seuil.

Krog, Antjie (2004) 'Reading with the Skin: Liberalism, Race and Power in Age of Iron and Disgrace by J.M. Coetzee', in Kader Asmal (ed.) In His Own Words. Boston, MA: Little, Brown and Company.

Mamdani, Mahmood (2001) 'A Diminished Truth', pp. 58-61 in Wilmot James and Linda van de Vijver (eds) After the TRC: Reflections on Truth and Reconciliation in South Africa. Claremont/Athens: David Philip/Ohio University Press.

Minow, Martha (1998) Between Vengeance and Forgiveness: Facing History after Genocide and Mass Violence. Boston, MA: Beacon.

Morrison, Toni (1992) Playing in the Dark: Whiteness and the Literary Imagination. Cambridge, MA: Harvard University Press.

Postel, Gitte (2006) Unheimlich moederland. (Anti-)pastorale letteren in Zuid-Afrika. Leiden: Leiden University Press.

Rossouw, Johann (2005) 'O moenie huil nie, o moenie treur nie, die jollie bobbejaan kom weer'., Vrye Afrikaan; at: vryeafrikaan.co.za/lees.php?id=105

Sage, Lorna (1994) Flesh and the Mirror: Essays on the Art of Angela Carter. London: Virago.

Sontag, Susan (1964) Against Interpretation. New York: Dell Publishing.

Spivak, Gayatri Chakravorty (1985) 'Three Women's Texts and a Critique of Imperialism', Critical Inquiry 12(1): 243-62.

Spivak, Gayatri Chakravorty (2003) Death of a Discipline. New York: Columbia University Press. 
Van Heusden, Barend (2001) Literaire Cultuur. Nijmegen: SUN.

Van Niekerk, Marlene (2004) Agaat. Jeppestown: Jonathan Ball.

Van Niekerk, Marlene (2007) Agaat, trans. Michiel Heyns. Jeppestown: Jonathan Ball.

Visagie, Andries (2005) 'Agaat as kultuurdokumentasie vir die toekoms', LifNet February; at: www.litnet.co.za/cgi-bin/giga.cgi?cmd=cause_dir_news_ item\&news_id=17768\&cause_id=1270

Rosemarie Buikema is Professor of Art, Culture and Diversity at Utrecht University. She is scientific director of the Graduate Gender Programme and head of the Department of Media and Culture Studies. She has published widely on feminist theory, cultural critique, postcolonialism, transitional justice and literary theory. She recently edited Gender in Media Art and Culture (with Iris van der Tuin; Routledge, 2009). Address: Muntstraat 2A, 3512 EV Utrecht, The Netherlands. [email: R.L.Buikema@uu.nl] 